\title{
Aggregation of public choice in Russia: national projects' potential
}

\author{
Yan Vaslavsky ${ }^{1, *}$ \\ ${ }^{1}$ Moscow State Institute for Foreign Relations (MGIMO University) \\ 119454, Moskva, Russian Federation
}

\begin{abstract}
Adequacy of individual values reflection in the resulting public choice on the national level is extremely significant in itself. However, in the conditions of stagnating economy and declining citizens' welfare this problem aggravates on the background of growing conflicting interests in the society and "accusations" against the state because of decline of population real income. In these conditions, the urgency of the problem of the adequacy of public choice in any country increases from both theoretical and practical view points. Moreover, its significance is great in the context of the experience of Russia as a typical economy with emerging market. The author sets the goals of considering the Russian experience of aggregating individual values and assessing the adequacy of the state's public choice related to the implementation of national projects in the field of socially significant infrastructure. The goals are achieved through the application of general scientific research methods in the framework of comparative, logical, statistical analysis, as well as through the analysis of structure and dynamics, graphical interpretation of the information provided, etc. As a result, universal problems of public choice in the countries of the world were identified, the public-private partnership was highlighted as the real base and the effective mechanism of aggregation of individual values for the implementation of national projects. This made it possible to demonstrate the effectiveness of public choice in the field of socially significant infrastructure and to test effective forms of cooperation with national private business. In this light, Russia's choice in favour of national projects as a special technology of aggregation of individual values represents interest both for theorists and practitioners.
\end{abstract}

\section{Introduction}

The dialectical approach to the phenomena considered above makes it possible to assert that economic uncertainty in the world, on the one hand, is determined by the quality of the institutional structure in society, and, on the other hand, it itself determines the structure of formal institutions that allow the state to ensure the functioning of the mechanism of aggregation of individual values for implementation purposes of public choice [1]. Moreover, the results of this interaction in different national communities can be completely opposite. This is explained by the fact that in the highly structured modern national systems, the

\footnotetext{
* Corresponding author: vaslavsky@yandex.ru
} 
mechanisms of public choice, including formal institutions and the economic policy of the state, are distinguished by a large variety and technology of aggregating individual values under the slogan of benefit for the whole society [2]. However, national socio-economic systems are a combination of diverse interrelations of economic agents that adhere to, often conflicting norms of behavior and social values. As a result, the public choice, mediated by the mechanism in the hands of the state, implements the balanced political and economic result in society from the set of individual values. At the same time, the political and economic resultant embodies the structure of interests (values, norms of behavior) of entities or their groups that dominate the economic, institutional and political environment (prevailing reality), conflict resolution mechanisms of their interests and models of aggregation of their competing individual values [3].

The state, which is responsible for ensuring the homeostasis of the national system, uses the various possibilities of aggregation mechanisms to resolve the most acute contradictions in society, which can definitely violate its stability [4]. To do this, various political institutions are used that can resolve the most pressing conflicts that arise in the process of aggregating individual values to ensure public choice. It is in this sense that it is necessary to assess the relationship between formal and informal institutions, the institutional environment and factors of economic growth and integrate them into political and economic models of collective choice. This approach makes it possible to assess the ability to identify the essence and forms of manifestation of conflicts of interest and values, which are guided by the main economic and political players in their behavior. In this context, one should understand the words of the founder of the World Economic Forum, Klaus Schwab, that today the economic system of any nationality must increasingly transform "shareholder capitalism" into "stakeholder capitalism". In the context of the aggravation of fundamental problems associated with drivers of the development of socio-economic systems in the future, the state, its motivation, norms of behavior and mechanisms for adequately ensuring the collective choice of priority values in society should also change. In this regard, the preferences of the state in terms of those institutional and political mechanisms that mediate the aggregation of individual values should become transparent. Therefore, the political and economic models that are generated by states in different national communities differ in technologies for resolving the state's confrontation with individual humans or their dominant groups on the economic strategy of the future [5].

The state is the central element of national socio-economic systems. Performing the functions imputed to him by society, it realizes the regulating (organizing) principle in them, strengthening their sustainability. The historical realities and theoretical developments of scientists made it possible to interpret the causes and factors of the emergence and functioning of the state in connection with the objective need to ensure the integrity of socioeconomic systems. To this end, national communities charge the states with the obligation to perform certain functions that are gradually increasing. Conventionally, all the functions of modern states can be reduced to the production and offer of public goods [6]. Such representatives of institutional theory as D. North [7] and his followers [8] specified the activity of the state as the agency that "sells" public goods and services like "defense and justice" in a market economy in exchange for taxes and other obligatory payments from the society to the state budget.

However, in addition to participating in the redistribution of gross domestic product through public finances, the state provides institutional support for market relations [9]. Providing the functioning of the entire socio-economic system with formal institutions, the state realizes the functions of a discriminating monopolist. It differentiates economic agentstaxpayers by groups, specifies property rights for each of them in order to maximize tax revenues to the state budget. Actually, this is one of the mechanisms for aggregating individual preferences (values) of economic agents through their institutionalization in the 
form of public choice.

The method of presenting the material is subject to the dialectical principle "from general to particular" and is as follows: first, there are presented theoretical aspects related to public choice, and there is considered its implementation by the state on the basis of formal institutions, and, second, the author substantiates Russia's choice of public choice technology in connection with infrastructure projects that have received national significance, and analyzes the possibilities of their successful implementation on the basis of PPP. At the end there are the results and discussion, as well as the conclusion and references.

\section{Formal institutions and the aggregation of individual values in the economy}

The list of functions of the state is not limited to the activities described above. In modern conditions, there becomes the fundamental issue on the state's implementation of such a public choice that would aggregate the individual values of the majority of citizens, creating a sense of social justice, trust in the state regarding materially secured old age, of adequate medical care, and of implementation of laws, etc. In the context of increasing socio-economic inequality in the world, a reduction in the middle class, increased corruption in the highest echelons of power, an increase in the informal segment in national economies, the problem of the adequacy of aggregation of individual values and of the coherence of public choice is becoming increasingly important.

The institutional support of market relations in the modern economy determines not only economic growth, but also social stability, continuity of generations, the effectiveness of the social contract between society and the state, and much more. However, the economy is dominant, since it is precisely the level of GDP and its annual growth rate that determine the living standards that citizens can count on. This fact is especially relevant at the end of 2019, as the economic dynamics in the world is more likely to stagnate than to accelerate the growth. Daron Acemoglu [10] believes that institutional changes in the world are the key to understanding the reasons for the beginning of global economic growth more than 200 years ago and its inhibition, starting with the global financial crisis of 2007-2009. Moreover, states must reevaluate many established phenomena in a complex, specialized and integrated society of economic agents, taking into account national specificities and differentiated individual values of citizens [11].

It should be noted that the really existing national communities today give diametrically opposed socio-economic results only because of fundamental differences in their institutional structures. As an example, South and North Korea are usually cited. It turns out that one structure of formal (and informal) institutions stimulates rapid economic growth, as is the case with South Korea, and another variant of institutional mechanisms provides economic stagnation (for example, in North Korea). This begs the important question: why do some national communities collectively prefer formal institutions that ensure economic growth, while others vote for institutions that determine economic stagnation? If this question is to be adapted to modern realities, then it extends to institutional reasons that determine the inhibition of economic growth all over the world after the global financial crisis of 20072009.

According to the IMF data of January 2020 [12], global economic growth is slowing. By the end of 2019 the global economic growth decreased to $2.9 \%$ compared with $3.8 \%$ in 2017 (Fig. 1). Moreover, this indicator was the lowest since the global financial crisis of 20072009. The IMF predicts an increase in global economic growth to $3.4 \%$ in 2020 . But this increase does not apply to all countries in the world to the same extent, and economic growth itself can hardly be stable. 


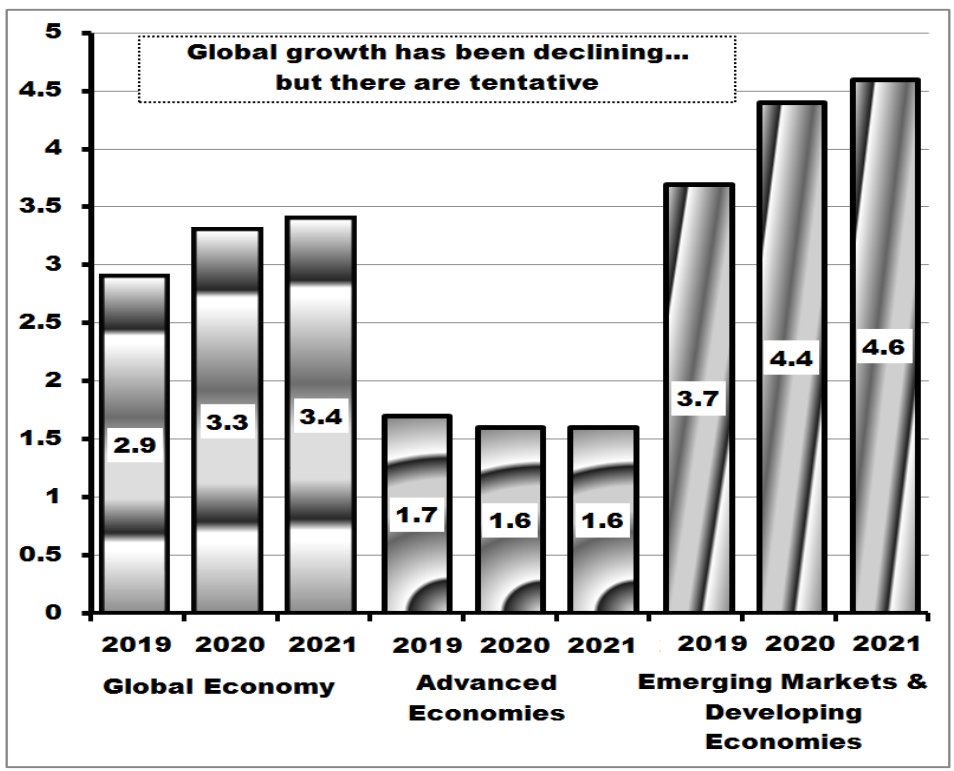

Fig. 1. IMF growth projections: global economy, advanced economies, emerging markets \& developing economies, 2019-2021 (GDP, \%) [12]

\section{Development of socially significant infrastructure in the context of adequate aggregation of individual values in a stagnant economy}

Numerous studies have proved that the most acceptable model of public choice from the point of view of the state is the development of socially significant infrastructure that can keep the national economy from negative values of economic growth.

Consideration of infrastructure PPP projects as drivers of economic growth is based on assessments of international expert organizations. Thus, according to the World Bank estimates, global GDP will double by 2030 , the volume of air transportation will increase annually by $4.7 \%$, cargo transportation by $5.9 \%$, and container transportation by $6 \%$ during this period [13]. The key factors in the growth of infrastructure are the growth of the world's population and its urbanization, the growth of population incomes, and, consequently, the expansion of international trade and tourism. This could lead to a doubling of the scale of passenger air transportation in the next 10-15 years, cause a threefold increase in freight traffic, and a fourfold increase in container traffic during this period of time. Moreover, only to maintain the current level of world GDP, national governments should spend at least $3.5 \%$ of world GDP (3.2 trillion US dollars) per year on infrastructure. In this case, for the period from 2015 to 2030, the total amount of these expenses should have increased to $\$ 57$ trillion [14]. If it is necessary to take into account the rapid growth of demand factors for infrastructure in the future, then this will not be enough to ensure the rapid growth of cargo turnover in the coming decades. Thus, the above amount of $\$ 57$ trillion by 2030 ( $\$ 3.2$ trillion per year) will be clearly insufficient to ensure economic growth, given the existing scale of infrastructure. Such a level of investment will not allow increasing the capacity of the main transport corridors in the world and increasing transportation by almost 1.5 times by 2030 , not to mention doubling them. 
Developed countries need to build new links between existing routes, expand "bottlenecks" and maintain existing infrastructure, and developing ones need to significantly expand the length of transport networks. Such dynamics of demand for infrastructure services can turn them into the most important driver of economic growth in various countries of the world. However, this makes necessary to solve the difficult task of finding the necessary volumes of financing for large-scale infrastructure projects, with the possibility of diversifying its sources, as well as choosing the appropriate PPP forms for their "packaging" [15]. In this regard, national PPP projects in the field of socially significant infrastructure could well be associated with one of the forms of implementing collective choice technology under conditions of economic growth inhibition. In the context of budgetary constraints and the consolidation of budgetary funds, the collective choice is objectively oriented towards co-financing projects for the development of socially significant infrastructure to achieve the common goal of stabilizing economic growth

\section{National projects and the PPP mechanism in the model of public choice in Russia}

The global financial crisis of 2007-2009 had a significant negative impact on Russia. It is about inflationary shock and accelerating price increases to $11.4 \%$ by the end of 2014 , the Central Bank's urgent increase in the key rate to $17 \%$, and a steady reduction in real disposable incomes of the population: by $3.2 \%$ in 2015 and $5.9 \%$ in 2016 . As a result, the scale of consumer lending has grown significantly, which increased the share of household payments on unsecured consumer loans over the past two years from $7.5 \%$ to $8.4 \%$ of income, while the share of households with loans exceeded $40 \%$.

Even rising oil prices did not cause a significant increase in economic growth. In 2014, Russia experienced a "perfect" storm, which was accompanied by a fall in oil prices, the introduction of anti-Russian sanctions due to the Crimea, and the depreciation of the ruble by almost half. As a result, at the end of 2014, the economic growth was estimated at $0.7 \%$, in 2015 the absolute decline in GDP was $2.3 \%$, the situation did not significantly improve in 2016 [16]. Since 2017, the new budget rule fixed the cut-off price per barrel of exported oil at $\$ 40$, which led to an increase in the National Wealth Fund. As a result, a decrease in the dependence of the Russian economy on oil prices, the Central Bank's inflation targeting policy made it possible to achieve an inflation rate of $2.5 \%$ by the end of 2017 and after slightly exceeding the target indicator of 4\% (4.3\%) in 2018, and reach 3\% at the end of 2019 [17].

Under these conditions, the political and economic model, which determines public choice, aggregated such macroeconomic goals as increasing the life expectancy of the population up to 78 years, halving the poverty level, increasing the GDP growth rate to $3 \%$ annually, as well as increasing labor productivity, increasing the share of investments in GDP and etc. In May 2018, a presidential decree was signed that institutionalized these goals as priorities and specified the technology for aggregating individual values and implementing them as a public choice. It is about national projects, the total cost of which amounts to 25.7 trillion rubles, including 13.2 trillion from the federal budget, and 4.9 trillion from regional budgets. It is supposed to expand the practice of organizing infrastructure projects on the basis of various forms of PPP. The private business participation in their co-financing is supposed to reach 7.5 trillion rubles. In addition, it is planned to attract the additional funds for national projects by raising VAT in 2019 from 18 to $20 \%$ [18].

In Russia, investment in infrastructure is an average of 3.6-4.2\% of GDP, which is close to the global average. By 2020, infrastructure investment will reach $\$ 650$ billion (an average of $\$ 90$ billion per year). These funds are sufficient for moderate expansion of the 
infrastructure and gradual improvement of its quality, but not for accelerated growth. To ensure high rates of economic growth in the country, total infrastructure spending should be at least $4-5 \%$ of GDP per year (more than 4 trillion rubles) [19]. However for the period 2012-2017 the share of government investment in public infrastructure decreased from $3.7 \%$ of GDP to $2.4 \%$, respectively.

According to experts, in 2020, the contribution of national projects to GDP growth may amount to about 0.1 percentage points (of the general rate of $1.6 \%$ ), and in 2021, about 0.2 0.3 percentage points (of the total pace of 1.8\%) [20]. According to the most optimistic estimates, in 2019 PPP mechanisms could cover the need for infrastructure investments in the amount of not more than 480-500 billion rubles. To this could be added another 200 billion rubles. in the form of capital grants, which in 2019 were focused on stimulating private investment in capital-intensive infrastructure projects based on PPPs. As a result, the total uncovered budgetary plans, taking into account the potential for the application of PPP mechanisms, could be assessed as 1.3 trillion rubles. So there becomes necessity for a "budgetary maneuver" associated with the redistribution of government spending in favor of infrastructure.

\section{Results and Discussion}

In Russia, the market capacity of infrastructure PPP projects only in 2016 increased by almost a quarter compared to 2015. At the same time, the volume of investment obligations of private partners grew by almost 1.5 times to 1.3 trillion rubles respectively [21]. Nevertheless, the potential market size for PPP infrastructure projects in Russia is much larger and is estimated at 2.3 trillion rubles, more than a quarter of which were represented by the demand for private investment in 2017. According to InfraOne estimates, in 2019 about 400 billion rubles could have been mobilized through the "budgetary maneuver" for infrastructure goals (Table 1).

Table 1. Assessment of infrastructure gaps by Russian branches of economy in 2019 [22]

\begin{tabular}{|l|l|l|l|}
\hline Branches of economy & $\begin{array}{l}\text { Approved } \\
\text { budget } \\
\text { expenditures } \\
\text { in 2019, } \\
\text { billion } \\
\text { rubles }\end{array}$ & $\begin{array}{l}\text { Unfunded } \\
\text { needs in } \\
2019, \\
\text { billion } \\
\text { rubles }\end{array}$ & $\begin{array}{l}\text { PPP-based } \\
\text { additional } \\
\text { funding } \\
\text { potential, } \\
\text { billion } \\
\text { rubles }\end{array}$ \\
\hline Public health & 44.7 & 100 & $30(30 \%)$ \\
\hline $\begin{array}{l}\text { Physical } \\
\text { cculture and } \\
\text { sport }\end{array}$ & 13.4 & 40 & $20(50 \%)$ \\
\hline Education & 24.3 & 40 & $20(50 \%)$ \\
\hline Culture and tourism & 12.9 & 20 & $15(75 \%)$ \\
\hline $\begin{array}{l}\text { Utility and energy } \\
\text { infrastructure }\end{array}$ & 41.1 & 300.0 & $120(40 \%)$ \\
\hline $\begin{array}{l}\text { Transport } \\
\text { infrastructure }\end{array}$ & 626.9 & 950.0 & $220(23 \%)$ \\
\hline IT- infrastructure & 0.8 & 50.0 & $35(70 \%)$ \\
\hline Agricultural infrastructure & 35.0 & 50.0 & $10(20 \%)$ \\
\hline $\begin{array}{l}\text { Other } \\
\text { industries }\end{array}$ & 5.3 & 50.0 & $12.5(25 \%)$ \\
\hline
\end{tabular}


In other words, the potential marginal amount of funds of the "infrastructure fund", which includes funds both in PPP projects in the form of a capital grant and in purely "budget" construction projects, in 2019 should have amounted to about 1.1 1.5 trillion rubles, taking into account the willingness of the state to redistribute the budget in favor of infrastructure [23]. Moreover, according to expert estimates, it is possible to ensure the minimum level of development of the country by means of a market supply of at least 300-500 infrastructure PPP-projects over the next 5-10 years with a total cost of at least 6 trillion rubles [24].

The countries of the world that relied on private money in infrastructure began with the creation of specialized institutions that coordinate investments. In 2011, a program for the development of high-speed roads and railways worth $€ 11$ billion was launched in Spain. France has a specialized state guarantee scheme for priority PPP projects, for which $€ 10$ billion are allocated per year. Mexico has set up a $\$ 20$ billion national infrastructure fund from which PPP projects are co-financed [25].

PwC experts analyzed the infrastructure investments in the crisis period, and noted that in the face of limited funding, national governments of all countries of the world should have to increase capital investments to infrastructure projects using the budgetary funds. Those governments that would fail to prepare the necessary institutional conditions for expanding the practice of co-investing in infrastructure PPP projects will be forced to observe the flows of national private capitals aiming at infrastructure projects in other countries such as India, Brazil, China, as well as OECD countries.

The problem of the national projects realization on the base of PPP in Russia is caused, first of all, by the inadequate formal institutions created by the state to ensure the spending of budget funds in partnership with private business. This is manifested in the state of the Russian financial market, which, together with most Russian commercial banks, cannot adequately perform the functions of accumulating savings and transforming them into project investments, especially in the field of public infrastructure. As a result, contradictions between individual values and social choice accumulate. This is due to the fact that in modern conditions, budgetary restrictions in Russia do not allow financing such capital-intensive national projects in full.

As a result, it turns out that the implementation of national projects in Russia is directly related to the state of the modern market for infrastructure PPP projects, characterized by the following features: on the one hand, there are unlimited opportunities for their rapid development, and, on the other, there are no necessary institutional conditions for this. Such a dialectic of the national projects and of the state of the modern Russian market of infrastructure PPP-projects is explained by the fact that the demand for professionally prepared options is quite significant, including potential investors willing to invest in them. The potential supply of infrastructure PPP projects is virtually unlimited, given the state of infrastructure facilities that have been preserved since Soviet times. In other words, there is both demand and supply in this market, and a negligible amount of real transactions. This is due to the fact that in addition to the necessary conditions for the development of any phenomenon, sufficient conditions must also be present. If the first component of expanding the practice of implementing infrastructure PPP projects is obvious, then the second component is absent. This is due to the lack of a system of formal institutions that ensure all stages of the implementation of these projects, provided that the transaction costs of partners are minimized, economic uncertainty is reduced, and the partners 'multiple risks are reduced, starting with the possible extension of project implementation timelines and ending with the likelihood of bankruptcy. This predetermines the gap between the individual preferences of citizens in the field of public infrastructure and their aggregation as public choice. 


\section{Conclusion}

Even with adequate aggregation of individual values in the period of economic stagnation and the availability of effective technology of public choice, as in the case of national projects, the absence of the necessary formal institutions and the inadequate fulfillment by the state of functions for the production of public goods can ruin any excellent idea. This is the situation in Russia today in the implementation of national projects in the field of socially significant infrastructure using the potential of PPP.

At the same time, PPP projects in any field, especially in infrastructure, should be either very good or none. Moreover, only in the first case will the technology of attracting private investments to implement capital-intensive long-term projects work, the state is not able to provide their full budget financing. Otherwise, there will be neither a quality infrastructure, nor a positive economic effect. As a result, the gap between the individual values of citizens and the public choice, which is predetermined by formal institutions under the leadership of the state, will increase. This will negatively affect the population's value judgments of the public choice technology selected by the state. As a result, everyone will lose: society and the population, a positive theory of public choice and normative practice of state regulation.

\section{References}

1. Arrow Kenneth J. Social Choice and Individual Values. London: Yale University Press (1963)

2. Schwab K. What capitalism do we need? Vedomosti. 12.02.2019

3. Bergson A. A reformulation of certain aspects of welfare economics. Quarterly Journal of Economics. 52, 310-334, February (1938)

4. Lange O. The foundations of welfare economics. Econometrica. 10, 215-228, July October (1942)

5. Estrin S., HanousekJ., Kočenda E., Svejnar J. The Effects of Privatization and Ownership in Transition Economies // Journal of Economic Literature. 2009. Vol. 47. No 3. P. 699728

6. Musgrave R. The role of the state in the fiscal theory. International Tax and Public Finance. J. 3, 247-258. (1996)

7. North D.C. Structure and Change in Economic History. New York: Norton (1981)

8. Arrow K.J. Political and economic evaluation of social effects and externalities. In: The Analysis of Public Output. Ed. by J.Margolis. New York: Colombia University Press. 130 (1970)

9. Alchian A.A. Specifity, specialization, and coalitions. J. of Institutional and Theoretical Economics. 140. 1. P. 34-49 (1984)

10. Acemoglu D. Introduction to Modern Economic Growth. Princeton: Princeton University Press (2009)

11. Vaslavsky, Y.I., and I.Yu. Vaslavskaya. Public-Private Partnership: An Institutional Approach. Moscow: ASPEKT PRESS (2019)

12. IMF. World Economic Outlook Update. January (2020)

13. Hallegatte, Stéphane, Jun Rentschler, and Julie Rozenberg. Lifelines: The Resilient Infrastructure Opportunity. Sustainable Infrastructure Series. Washington, DC: World Bank (2019)

14. Infrastructure Investments. Analytical Review. Executive Summary. Moscow: InfraONE, Roscongress (2019)

15. Vaslavsky Y, and I. Vaslavskaya. Infrastructure public-private partnership projects: budget consolidation policy in Russia and government expenditures efficiency increase In: Modeling Economic Growth in Contemporary Russia. Edited by Bruno S. Sergi. 
Bingley: Emerald Publishing (2019)

16. World Bank. Russia Economic Report. \#42. December 4 (2019)

17. Rosstat. Official statistics. Prices. Russia. (2019). Retrieved from: http://old.gks.ru/wps/wcm/connect/rosstat main/rosstat/ru/statistics/tariffs/\#.

18. Infrastructure Investment: at which point investors' interests meet government concerns. Analytical Review. Moscow: InfraONE (2019)

19. Global lessons on financing infrastructure: infrastructure round table. Lagos: McKinsey \& Company (2013)

20. World Bank. Russia Economic Report. \#42. December 4 (2019)

21. Vedomosty. 01.06.2017

22. InfraONE. National Infrastructure Projects Pipeline. Analytical review. Moscow: InfraONE (2019)

23. InfraONE. National Infrastructure Projects Pipeline. Analytical review. Moscow: InfraONE (2019)

24. Vedomosty. 28.11.2017

25. Hallegatte, Stéphane, Jun Rentschler, and Julie Rozenberg. Lifelines: The Resilient Infrastructure Opportunity. Sustainable Infrastructure Series. Washington, DC: World Bank (2019) 